\title{
Stream Sediment Geochemistry of Four Small Drainages on the North Shore of Kauai West of Hanalei
}

Open-File Report 2019-1007 
Cover. Photograph of Ha`ena Beach Park and hillslopes of Manoa watershed, Kauai, under low clouds on August 1, 2016 (U.S. Geological Survey photograph by Renee Takesue). 


\section{Stream Sediment Geochemistry of Four Small Drainages on the North Shore of Kauai West of Hanalei}

By Renee K. Takesue and Curt D. Storlazzi

Open-File Report 2019-1007 


\title{
U.S. Department of the Interior \\ DAVID BERNHARDT, Acting Secretary
}

\author{
U.S. Geological Survey \\ James F. Reilly II, Director
}

U.S. Geological Survey, Reston, Virginia: 2019

For more information on the USGS - the Federal source for science about the Earth, its natural and living resources, natural hazards, and the environment-visit http://www.usgs.gov or call 1-888-ASK-USGS.

For an overview of USGS information products, including maps, imagery, and publications,

visit https://store.usgs.gov/.

Any use of trade, firm, or product names is for descriptive purposes only and does not imply endorsement by the U.S. Government.

Although this information product, for the most part, is in the public domain, it also may contain copyrighted materials as noted in the text. Permission to reproduce copyrighted items must be secured from the copyright owner.

Suggested citation:

Takesue, R.K., and Storlazzi, C.D., 2018, Stream sediment geochemistry of four small drainages on the north shore of Kauai west of Hanalei: U.S. Geological Survey Open-File Report 2019-1007, 11 p., https://doi.org/10.3133/ ofr20191007

ISSN 2331-1258 (online) 


\section{Contents}

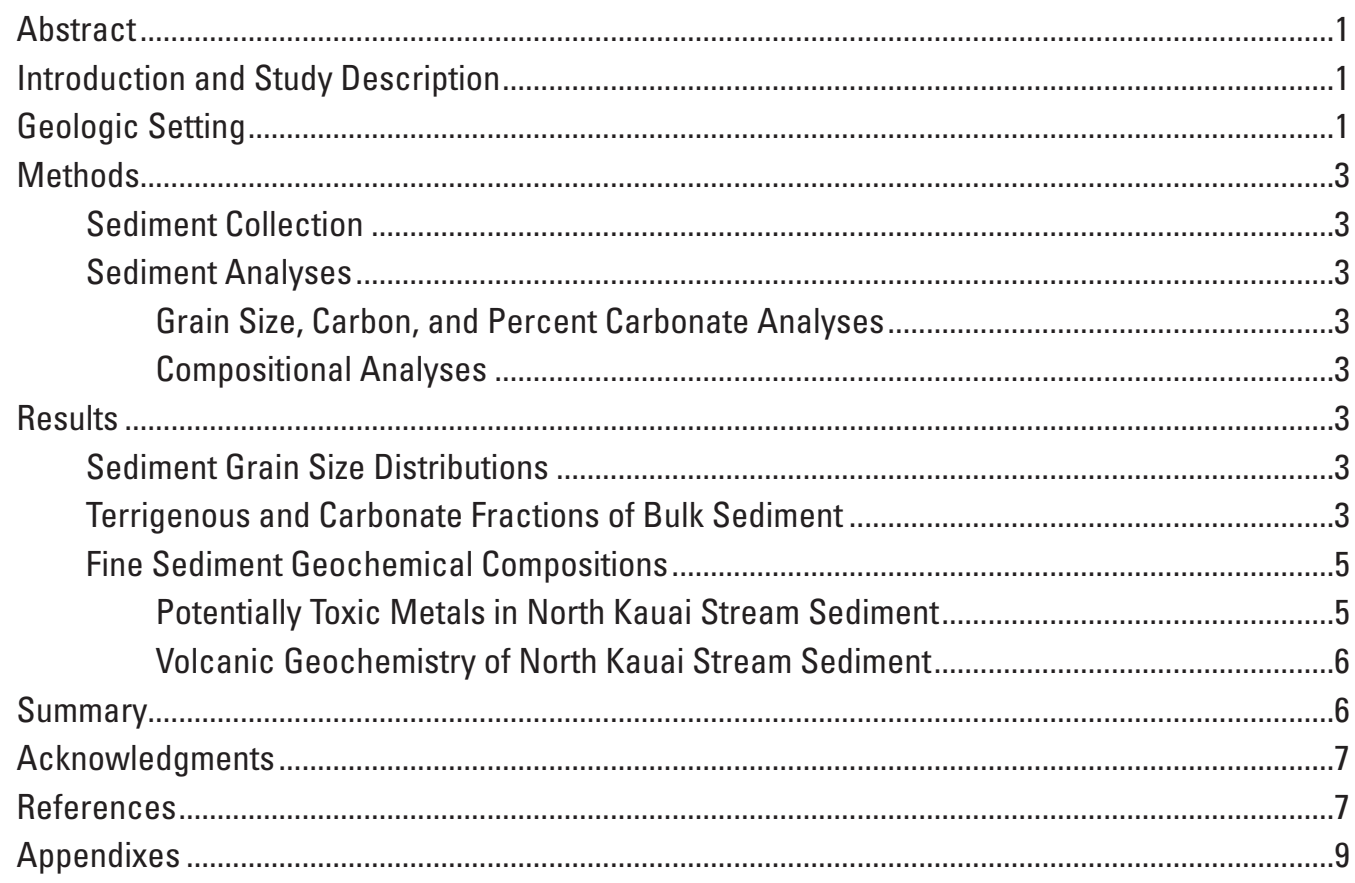

\section{Figures}

1. Google Earth satellite images of the study area showing sampling sites...

.2

2. Scatter plots of nickel, chromium, and rubidium contents relative to titanium contents in fine sediment from Limahuli Stream, Manoa Stream, Wainiha Stream, Lumahai Stream, and the back beaches of Limahuli and of Wainiha.

\section{Tables}

1. List of sediment collection dates, locations, descriptions, types, and percentages of less than 63 -micrometer-diameter particles and terrigenous material....................................4

2. Contents of potentially toxic metals in fine sediment from Limahuli Stream, Manoa Stream, 
Conversion Factors

International System of Units to U.S. customary units

\begin{tabular}{|c|c|c|}
\hline Multiply & By & To obtain \\
\hline \multicolumn{3}{|c|}{ Length } \\
\hline centimeter $(\mathrm{cm})$ & 0.3937 & inch (in.) \\
\hline millimeter (mm) & 0.03937 & inch (in.) \\
\hline meter $(\mathrm{m})$ & 3.281 & foot $(\mathrm{ft})$ \\
\hline kilometer $(\mathrm{km})$ & 0.6214 & mile (mi) \\
\hline kilometer $(\mathrm{km})$ & 0.5400 & mile, nautical (nmi) \\
\hline meter $(\mathrm{m})$ & 1.094 & yard (yd) \\
\hline \multicolumn{3}{|c|}{ Volume } \\
\hline liter $(\mathrm{L})$ & 33.81402 & ounce, fluid (fl. oz) \\
\hline liter $(\mathrm{L})$ & 2.113 & $\operatorname{pint}(\mathrm{pt})$ \\
\hline liter $(\mathrm{L})$ & 1.057 & quart (qt) \\
\hline liter $(\mathrm{L})$ & 0.2642 & gallon (gal) \\
\hline liter (L) & 61.02 & cubic inch (in3) \\
\hline \multicolumn{3}{|c|}{ Mass } \\
\hline $\operatorname{gram}(\mathrm{g})$ & 0.03527 & ounce, avoirdupois (oz) \\
\hline kilogram (kg) & 2.205 & pound avoirdupois (lb) \\
\hline
\end{tabular}

Temperature in degrees Celsius $\left({ }^{\circ} \mathrm{C}\right)$ may be converted to degrees Fahrenheit $\left({ }^{\circ} \mathrm{F}\right)$ as: ${ }^{\circ} \mathrm{F}=\left(1.8 \times{ }^{\circ} \mathrm{C}\right)+32$.

\section{Datum}

Horizontal coordinate information is referenced to the World Geodetic System standard of 1984 (WGS84).

\section{Abbreviations}

GS

grain size

$\mathrm{Ma} \quad$ millions of years ago

$\mathrm{mg} / \mathrm{kg} \quad$ milligram per kilogram

TC total carbon

TIC total inorganic carbon

USGS U.S. Geological Survey

\section{Chemical Symbols Used}

$\begin{array}{ll}\mathrm{Cd} & \text { cadmium } \\ \mathrm{Co} & \text { cobalt } \\ \mathrm{Cr} & \text { chromium } \\ \mathrm{Cu} & \text { copper } \\ \mathrm{Ni} & \text { nickel } \\ \mathrm{Pb} & \text { lead } \\ \mathrm{Rb} & \text { rubidium } \\ \mathrm{REE} & \text { rare earth elements } \\ \mathrm{Ti} & \text { titanium } \\ \mathrm{Zn} & \text { zinc } \\ \mathrm{Zr} & \text { zirconium }\end{array}$




\title{
Stream Sediment Geochemistry of Four Small Drainages on the North Shore of Kauai West of Hanalei
}

\author{
By Renee K. Takesue and Curt D. Storlazzi
}

\begin{abstract}
Geochemical compositions of fine-grained stream sediment from four drainages on the north shore of the island of Kauai, Hawaii, west of Hanalei and two back-beach sites were explored to increase understanding about land-based runoff and ecological risk from runoff to nearshore coral communities. Stream and beach sediment was collected between July 30 and August 2, 2016, and major, minor, and trace elements in the less than 63 micrometer-diameter fraction were analyzed by inductively coupled plasma optical emission spectroscopy and mass spectroscopy. The potentially toxic metals $\mathrm{Cr}, \mathrm{Cu}, \mathrm{Ni}$, and $\mathrm{Zn}$ exceeded levels at which adverse biological effects could be observed; however, these metals seemed to be largely mineral-bound and thus were unlikely to harm organisms. $\mathrm{Cd}$ and $\mathrm{Pb}$ were below levels of ecological concern. Only a small amount of fine-grained sediment was retained on beaches west of Hanalei sampled in summer 2016 (mean $=8.8$ percent, median $=0.4$ percent, range $=0-92.8$ percent, $\mathrm{n}=41$ ). Although the scarcity of fine-grained sediment precluded landbased runoff sourcing to the nearshore region, it did indicate that fine-grained sediment and associated contaminants did not accumulate over the long term in the sampled intertidal, subtidal, and reef-flat environments, which would reduce sediment-related pressures on coral communities there.
\end{abstract}

\section{Introduction and Study Description}

Human development and use of coastal zones is linked to increased deliveries of land-based sediment, nutrients, and contaminants to coastal ecosystems (Mee, 2012). Owing to the substantial economic and cultural benefits that healthy and productive coral reefs provide, the State of Hawaii has prioritized the reduction of land-based pollution impacts (Hawaii Department of Health, 2015). The study described in this report aimed to identify watershed sources of terrigenous, or land-derived, sediment and any sediment-bound potentially toxic metals to the coastal zone in the Wainiha region on the north shore of the Island of Kauai, Hawaii, west of Hanalei. The coastal road in this region is used daily by 2,300 vehicles on average (Hawaii Department of Transporation, 2017) and crosses four streams that deliver land-derived materials to the nearshore region. This study is part of a larger study exploring the role of land-based runoff as a factor contributing to coral disease in Kauai (Aeby and others, 2011). Such knowledge would help guide watershed restoration and runoff mitigation efforts to areas where they are most needed.

The study consisted of two components that characterized the geochemical compositions of stream and nearshore sediment. For the watershed component, the geochemical compositions of fine-grained stream sediment ( $<63$ micrometers) from four drainages west of Hanalei (from west to east: Limahuli, Manoa, Wainiha, and Lumahai; fig. 1) were explored to determine whether any had distinctive compositional characteristics, or signatures, that would allow downstream sediment deposits to be attributed to geographic and geologic source regions, and whether any had elevated levels of potentially toxic metals. Sediment geochemical sourcing requires that contributing basins contain compositionally distinct rock types whose geochemical signatures are quantitatively transferred into eroded and transported sediment exported from the basins (Fralick and Kronberg, 1997). For the nearshore component, the percentage of terrigenous material in bulk beach sediment was determined along the 6-kilometer-long stretch of shore from Ke'e Beach to Lumahai Beach (fig. 1). Additionally, the geochemical compositions, including potentially toxic metal contents, of fine-grained sediment on those beaches were determined and compared to ecological thresholds in order to assess potential impacts of land-derived sediment and contaminants on nearby coral reef communities.

\section{Geologic Setting}

Kauai is the second oldest of the Main Hawaiian Islands (Garcia and others, 2010), and its highly eroded volcanic peaks and lavas are covered with thick soils (MacDonald and others, 1960). The Waimea Canyon Basalt forms most of the island of Kauai and consists largely of shield stage olivine basalts and post-shield stage transitional alkalic lavas (MacDonald and others, 1960) that erupted 4-6 million years ago (Ma) (Garcia and others, 2010). Rejuvenated-stage alkalic lavas of the Koloa Volcanics erupted 0.1-4 Ma (Cousens and 

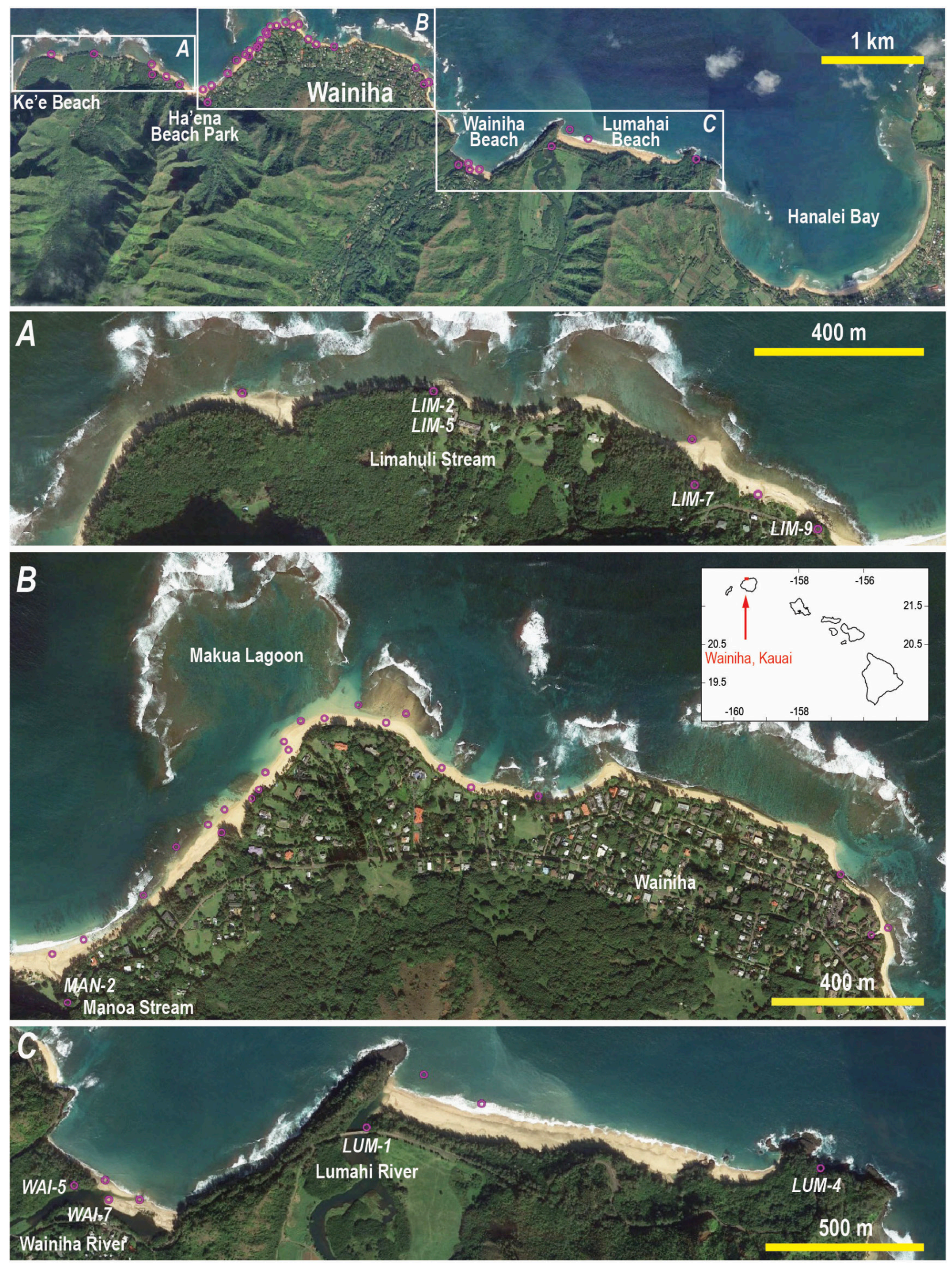

Figure 1. Google Earth satellite images of the study area showing sampling sites (open circles). Nine sites with geochemical data are labeled in $(A)$ Limahuli Stream, $(B)$ Manoa Stream and Makua Lagoon, and $(C)$ Wainiha and Lumahai Rivers. Inset shows the study location in the main Hawaiian Islands. 
Clague, 2015) and comprise less than 5 percent of the volume of the island (Garcia and others, 2010). The drainages on the north shore of Kauai west of Hanalei formed in Waimea Canyon Basalt and contain outcrops of alkalic Koloa lavas at Wainiha Beach and Lumahai Beach (Sherrod and others, 2007).

\section{Methods}

\section{Sediment Collection}

Forty-one sediment samples were collected between July 30 and August 2, 2016, from the banks (7 samples) of Limahuli Stream, Manoa Stream, Wainiha River, and Lumahai River on the north shore of Kauai west of Hanalei, and from nearby beaches and Makua Lagoon (34 samples) (fig. 1; table 1). Sampling targeted deposits of fine-grained sediment. Acidcleaned sampling tools were used to collect stream and beach sediment and were disinfected with a 10 percent bleach solution between stream sites to prevent the spread of organisms. The upper 2 centimeters $(\mathrm{cm})$ of stream bank and intertidal beach sediment were scooped into plastic wire-top sample bags. Subtidal beach sediment was scooped into 250 milliliter (ml) polypropylene sample jars. Samples were shipped and stored frozen until processing.

\section{Sediment Analyses}

\section{Grain Size, Carbon, and Percent Carbonate Analyses}

Bulk sediment was analyzed for grain size (GS) distribution and percent carbonate (calculated from total inorganic carbon [TIC] content) by the U.S. Geological Survey (USGS) Pacific Coastal and Marine Science Center sediment laboratory. Particles with diameters greater than 2 millimeters $(\mathrm{mm})$ were separated by dry-sieving into quarter-phi intervals (size in $\mathrm{mm}=2^{\text {-phi }}$ ) and weighed by size class. Sediment GS distributions were determined on organic- and salt-free sediment. Organic matter was removed from the less than 2-mm-diameter sediment fraction with hydrogen peroxide, and soluable salts were removed by centrifugation in freshwater. Sand- and mud-sized particles $(2 \mathrm{~mm}-63 \mu \mathrm{m}$ and $<63 \mu \mathrm{m})$ were separated by wet sieving and quantified using a laser particle diffraction counter (Beckman Coulter Life Sciences). GS parameters were calculated with in-house statistical software according to the methods of Folk and Ward (1957). Total carbon (TC) and TIC were determined coulometrically (UIC, Inc.). Percent carbonate was calculated as TIC multiplied by 8.333 , the mass ratio of calcium carbonate to carbon. The terrigenous fraction was calculated as 100 minus the percent carbonate value.

\section{Compositional Analyses}

Sediment was oven dried at 60 degrees Celsius and gently disaggregated with a mortar and pestle to avoid altering grain sizes. Disaggregated sediment was dry-sieved in stainless steel sieves to obtain 2 grams (g) of the $<63 \mu$ m-diameter (fine sediment) fraction, which was sent to the USGS Central Mineral and Environmental Resources Science Center Analytical Chemistry Project for geochemical compositional analyses. Total sediment decomposition with a sodium peroxide fusion and quantification by inductively coupled plasma optical emission spectroscopy (ICP-OES) and inductively coupled plasma mass spectroscopy (ICP-MS) was used to analyze contents of major, minor, and trace elements (Morrison and others, 2009). The total decomposition was optimal for determinations of rare earth elements (REEs) and other elements in refractory minerals such as chromium $(\mathrm{Cr})$ and zirconium $(\mathrm{Zr})$. Neartotal sediment decomposition with a four-acid mixture and quantification by ICP-OES and ICP-MS was used to analyze contents of major, minor, and trace elements, and was optimal for trace element determinations (Goldhaber and others, 2009).

Major element contents are reported in units of percent, and minor and trace element content are reported as milligrams per kilogram $(\mathrm{mg} / \mathrm{kg})$. Duplicate samples had a relative standard deviation no greater than 15 percent, and compositional values were within \pm 15 percent at five times the lower limit of determination. To account for differences in the terrigenous content of the fine sediment fraction, compositional data were referenced to titanium (Ti), a component of primary basaltic minerals that does not have an urban source in Hawaii (Sutherland and Tolosa, 2000). A positive correlation with Ti is characteristic of a basalt-hosted element, and a lack of correlation with $\mathrm{Ti}$ is characteristic of an element associated with non-basaltic material, such as an alkalic lava (Hanano and others, 2010).

\section{Results}

\section{Sediment Grain Size Distributions}

Seventeen of 41 samples were composed of 1 percent or more fine sediment (table 1). The median grain sizes of 7 stream samples ranged from medium sand $(250-500 \mu \mathrm{m})$ to clay-sized $(<4 \mu \mathrm{m})$ sediment. The median grain sizes of 34 beach samples ranged from very coarse sand $(1-2 \mathrm{~mm})$ to medium sand $(0.250-0.500 \mathrm{~mm})$.

\section{Terrigenous and Carbonate Fractions of Bulk Sediment}

Bulk stream sediment consisted of 56-100 percent terrigenous material (table 1), with a mean of 87 percent and a 
Table 1. List of sediment collection dates, locations, descriptions, types, and percentages of less than 63-micrometer-diameter particles (FIN) and terrigenous material (TERR).

[ID, identification number; \%, percent; LIM, Limahuli Stream; MAN, Manoa Stream; WAI, Wainiha Stream; LUM, Lumahai Stream; B, beach sample.]

\begin{tabular}{|c|c|c|c|c|c|c|c|}
\hline Site ID & Date & Latitude & Longitude & Description & Type & FIN $(\%)$ & TERR $(\%$ \\
\hline LIM-1 & $7 / 29 / 16$ & 22.22379 & -159.57992 & Limahuli, intertidal & B & 0 & 77 \\
\hline${ }^{1}$ LIM-2 & $7 / 29 / 16$ & 22.22349 & -159.57713 & Limahuli, south stream bank & Stream & 39 & 100 \\
\hline LIM-3 & $7 / 29 / 16$ & 22.22382 & -159.57590 & Limahuli, intertidal & B & 0 & 66 \\
\hline LIM-4 & $7 / 29 / 16$ & 22.22382 & -159.57590 & Limahuli, subtidal & B & 0 & 35 \\
\hline${ }^{1}$ LIM-5 & $7 / 29 / 16$ & 22.22382 & -159.57590 & Limahuli, west stream bank & Stream & 17 & 56 \\
\hline LIM-6 & $7 / 30 / 16$ & 22.22289 & -159.57045 & West Ha'ena, intertidal & B & 0 & 28 \\
\hline${ }^{1} \mathrm{LIM}-7$ & $7 / 30 / 16$ & 22.22200 & -159.57040 & West Ha'ena, stream bank & Stream & 34 & 67 \\
\hline LIM-8 & $7 / 30 / 16$ & 22.22181 & -159.56907 & West Ha'ena, intertidal & B & 0 & 21 \\
\hline${ }^{1}$ LIM-9 & $7 / 30 / 16$ & 22.22114 & -159.56781 & Ha'ena, back beach & B & 9 & 34 \\
\hline MAN-1 & $8 / 1 / 16$ & 22.22071 & -159.56561 & Manoa, intertidal & B & 1 & 49 \\
\hline${ }^{1} \mathrm{MAN}-2$ & $7 / 30 / 16$ & 22.21958 & -159.56518 & Manoa, west stream bank & Stream & 52 & 88 \\
\hline MAN-3 & $7 / 30 / 16$ & 22.22105 & -159.56481 & Manoa, intertidal & B & 0 & 29 \\
\hline MAN-4 & $8 / 1 / 16$ & 22.22209 & -159.56328 & Manoa, subtidal & B & 0 & 4 \\
\hline MAK-1 & $8 / 1 / 16$ & 22.22323 & -159.56246 & Makua, subtidal & B & 0 & 16 \\
\hline MAK-2 & $8 / 1 / 16$ & 22.22376 & -159.56164 & Makua, subtidal & B & 0 & 22 \\
\hline MAK-3 & $8 / 1 / 16$ & 22.22357 & -159.56129 & Makua, intertidal & B & 0 & 8 \\
\hline MAK-4 & $8 / 1 / 16$ & 22.22411 & -159.56123 & Makua, subtidal & B & 2 & 10 \\
\hline MAK-5 & $8 / 1 / 16$ & 22.22437 & -159.56052 & Makua, subtidal & B & 0 & 18 \\
\hline MAK-6 & $7 / 30 / 16$ & 22.22458 & -159.56034 & Makua, intertidal & B & 0 & 11 \\
\hline MAK-7 & $8 / 1 / 16$ & 22.22499 & -159.56018 & Makua, subtidal & B & 0 & 5 \\
\hline MAK-8 & $8 / 1 / 16$ & 22.22571 & -159.55971 & Makua, subtidal & B & 1 & 6 \\
\hline MAK-9 & $7 / 30 / 16$ & 22.22552 & -159.55959 & Makua, intertidal & B & 1 & 37 \\
\hline MAK-10 & $8 / 1 / 16$ & 22.22620 & -159.55929 & Makua, subtidal & B & 1 & 6 \\
\hline MAK-11 & $7 / 30 / 16$ & 22.22626 & -159.55868 & East Makua, intertidal & B & 0 & 39 \\
\hline MAK-12 & $8 / 1 / 16$ & 22.22658 & -159.55782 & East Makua, subtidal & B & 0 & 8 \\
\hline MAK-13 & $7 / 30 / 16$ & 22.22616 & -159.55711 & East Makua, intertidal & B & 0 & 14 \\
\hline MAK-14 & $8 / 1 / 16$ & 22.22638 & -159.55660 & East Makua, subtidal & B & 1 & 5 \\
\hline MAK-15 & $7 / 30 / 16$ & 22.22510 & -159.55569 & East Makua, intertidal & B & 0 & 13 \\
\hline MAK-16 & $8 / 1 / 16$ & 22.22464 & -159.55495 & East Makua, intertidal & B & 0 & 46 \\
\hline WAI-1 & $8 / 1 / 16$ & 22.22443 & -159.55324 & East Makua, subtidal & B & 0 & 37 \\
\hline WAI-2 & $8 / 2 / 16$ & 22.22258 & -159.54554 & Wainiha Beach, intertidal & B & 0 & 54 \\
\hline WAI-3 & $8 / 2 / 16$ & 22.22116 & -159.54478 & Wainiha Beach, intertidal & B & 1 & 5 \\
\hline WAI-4 & $8 / 2 / 16$ & 22.22132 & -159.54433 & Wainiha Beach, intertidal & B & 0 & 27 \\
\hline${ }^{1}$ WAI-5 & $7 / 31 / 16$ & 22.21412 & -159.54153 & Wainiha Stream & Stream & 93 & 100 \\
\hline WAI-6 & $7 / 31 / 16$ & 22.21426 & -159.54061 & Wainiha Beach, intertidal & B & 1 & 58 \\
\hline${ }^{1} \mathrm{WAI}-7$ & $7 / 31 / 16$ & 22.21372 & -159.54049 & Wainiha sandbar & B & 1 & 54 \\
\hline WAI-8 & $7 / 31 / 16$ & 22.21372 & -159.53956 & Wainiha Beach, intertidal & B & 0 & 78 \\
\hline${ }^{1}$ LUM-1 & $7 / 31 / 16$ & 22.21573 & -159.53276 & Lumahai Stream & Stream & 30 & 97 \\
\hline LUM-2 & $7 / 31 / 16$ & 22.21720 & -159.53104 & Lumahai Beach, intertidal & B & 0 & 79 \\
\hline LUM-3 & $7 / 31 / 16$ & 22.21639 & -159.52931 & Lumahai Beach, intertidal & B & 0 & 82 \\
\hline${ }^{1}$ LUM-4 & $8 / 2 / 16$ & 22.21459 & -159.51914 & Lumahai runoff & Stream & 78 & 99 \\
\hline
\end{tabular}

'Samples with sufficient material for geochemical analysis of the less than 63-micrometer fraction. 
median of 97 percent. Stream sediment samples LIM-5 and LIM-7, which were collected near the mouth of Limahuli Stream and a tributary, contained 44 and 33 percent carbonate, material that could have been deposited by large wave events or past high stands of sea level (Calhoun and Fletcher, 1996; Morton and others, 2007). Bulk beach sediment consisted of 4-82 percent terrigenous material (table 1), with a mean of 32 percent and a median of 27 percent. The skew toward low terrigenous values in beach sediment shows that beaches were composed predominantly of carbonate grains.

\section{Fine Sediment Geochemical Compositions}

Nine samples had sufficient fine material for compositional analysis (denoted by footnote in table 1). Seven were from streams and two from the back-beach areas at Ha'ena Beach Park (LIM-9) and Wainiha Beach (WAI-7). Geochemical data are available in appendixes 1 (near-total compositions) and 2 (total compositions).

\section{Potentially Toxic Metals in North Kauai Stream Sediment}

The trace metals chromium $(\mathrm{Cr})$, copper $(\mathrm{Cu})$, nickel $(\mathrm{Ni})$, and zinc $(\mathrm{Zn})$ are naturally enriched in Hawaiian soils because they are incorporated in volcanic minerals in basaltic lavas (Sutherland, 2000). Because these elements are largely mineral-bound, they are not likely to be assimilated by organisms (Sutherland and Tolosa, 2000). Therefore, although total fine-sediment contents of $\mathrm{Cr}$ and $\mathrm{Ni}$ exceeded the probable effects concentration (PEC) for freshwater sediment (MacDonald and others, 2000) above which adverse biological effects are expected to occur more often than not (table 2), and $\mathrm{Cu}$ and $\mathrm{Zn}$ exceeded the threshold effects concentration (TEC) for freshwater sediment (MacDonald and others, 2000) above which adverse biological effect are sometimes expected to occur (table 2), the fractions of these metals that were available to organisms and food webs, called the bioavailable fractions, were expected to be below levels of biological concern (Sutherland and Tolosa, 2000). Lead (Pb) was slightly elevated in fine sediment from Manoa Stream below the highway crossing, and in fine sediment collected from the bank of Lumahai Stream under the highway bridge, but did not exceed the TEC (table 2). In the fine fraction of beach sediment, $\mathrm{Pb}$ and $\mathrm{Zn}$ contents were below the effect range low (ERL) level for estuarine sediment (Long and others, 1995), below which adverse biological impacts would rarely be observed; $\mathrm{Ni}$ contents exceeded the effect range median (ERM) level for estuarine sediment (Long and others, 1995), above which adverse biological impact are likely to occur; and $\mathrm{Cr}$ and $\mathrm{Cu}$ contents were intermediate. Cadmium contents were below levels of concern at all sites.

Table 2. Contents of potentially toxic metals in fine sediment from Limahuli Stream (LIM), Manoa Stream (MAN), Wainiha Stream (WAI), Lumahai Stream (LUM), and back beach areas (B).

$[\mathrm{mg} / \mathrm{kg}$, milligram per kilogram; TEC, threshold effects concentration; PEC, probable effect concentration; ERL, effect range low; ERM, effects range median.]

\begin{tabular}{|c|c|c|c|c|c|c|}
\hline & $\begin{array}{l}\text { Cadmium, } \\
\text { in } \mathrm{mg} / \mathrm{kg}\end{array}$ & $\begin{array}{c}\text { Chromium, } \\
\text { in } \mathrm{mg} / \mathrm{kg}\end{array}$ & $\begin{array}{c}\text { Copper, } \\
\text { in } \mathrm{mg} / \mathrm{kg}\end{array}$ & $\begin{array}{c}\text { Nickel, } \\
\text { in mg/kg }\end{array}$ & $\begin{array}{c}\text { Lead, } \\
\text { in } \mathrm{mg} / \mathrm{kg}\end{array}$ & $\begin{array}{c}\text { Zinc, } \\
\text { in } \mathrm{mg} / \mathrm{kg}\end{array}$ \\
\hline \multicolumn{7}{|c|}{ Stream sediment } \\
\hline LIM-2 & 0.21 & 845 & 152 & 317 & 2.8 & 148 \\
\hline LIM-5 & 0.19 & 1690 & 190 & 380 & 2.1 & 192 \\
\hline LIM-7 & 0.10 & 354 & 55 & 194 & 7.8 & 124 \\
\hline MAN-2 & 0.28 & 1160 & 240 & 386 & 26.1 & 293 \\
\hline WAI-5 & 0.15 & 640 & 127 & 297 & 3.4 & 128 \\
\hline LUM-1 & 0.23 & 930 & 112 & 407 & 32.8 & 177 \\
\hline LUM-4 & 0.12 & 942 & 161 & 267 & 7.3 & 166 \\
\hline$T E C^{I}$ & 0.99 & 43.4 & 31.6 & 22.7 & 35.8 & 121 \\
\hline$P E C^{l}$ & 4.98 & 111 & 149 & 48.6 & 128 & 459 \\
\hline \multicolumn{7}{|c|}{ Beach sediment } \\
\hline LIM-9 (B) & 0.12 & 317 & 73 & 127 & 8.3 & 79 \\
\hline WAI-7 (B) & 0.09 & 771 & 106 & 308 & 3.3 & 111 \\
\hline$E R L^{2}$ & 1.2 & 81 & 34 & 20.9 & 46.7 & 150 \\
\hline$E R M^{2}$ & 9.6 & 370 & 270 & 51.6 & 218 & 410 \\
\hline
\end{tabular}

${ }^{2}$ Long and others (1995) 


\section{Volcanic Geochemistry of North Kauai Stream Sediment}

Fine sediments of all nine stream and beach samples had Ni contents greater than $100 \mathrm{mg} / \mathrm{kg}$ and $\mathrm{Cr}$ greater than $300 \mathrm{mg} / \mathrm{kg}$ (fig. 2A, B), indicating that olivine basalts (Mukhopadhyay and others, 2003) were the dominant source of land-derived sediment to the north Kauai shore west of Hanalei. Cobalt (Co) and scandium (Sc), two other elements that are characteristic of basaltic lavas (Hanano and others, 2010), were closely correlated with $\mathrm{Cr}$ in stream and beach fine sediment $(r>0.80)$. Based on basaltic compositions that plot in overlapping fields relative to $\mathrm{Ti}$, sediment from the four drainages west of Hanalei Bay could not be distinguished geochemically (fig. 2A, $B$ ).

The alkali metal rubidium $(\mathrm{Rb})$ is enriched in alkalic Hawaiian lavas (Maaløe and others, 1992; Hanano and others, 2010). The low negative correlation of $\mathrm{Rb}$ and Ti contents (fig. $2 C$ ) showed that the alkalic element $\mathrm{Rb}$ was not associated with sediment derived from basalt in streams on the north Kauai shore west of Hanalei. $\mathrm{Rb}$ contents were elevated $(>8$ $\mathrm{mg} / \mathrm{kg}$ ) relative to Ti contents in fine sediment from Manoa Stream and an eroding seacliff at Lumahai Beach (red square and purple cross in fig. 2C), indicating that runoff from these drainages contained material from alkalic lavas that imparted a distinctive geochemical signature. Two samples from Wainiha and Lumahai Streams with slightly elevated $\mathrm{Rb}$ relative to $\mathrm{Ti}$ contents $(\sim 4-4.5 \mathrm{mg} / \mathrm{kg}$, green triangle and purple cross in fig. 2C) could also contain small amounts of alkalic material, consistent with the presence of alkalic olivine basalt outcrops at the mouths of these streams (Cousens and Clague, 2015). Fine-grained beach sediment at Limahuli and Wainiha beaches did not, however, contain distinguishable alkalic geochemical signatures relative to Ti contents (blue stars in in fig. 2C), reflecting the dominance of basaltic sediment sources west of Hanalei.
None of the beach-front intertidal, subtidal, or reef flat samples had sufficient fine sediment for compositional analyses, likely due to a high degree of reworking and winnowing by waves, so it was not possible to assess whether runoff from the four small drainages impacted the reef flat west of Hanalei.

\section{Summary}

Stream sediment geochemistry was determined in the sediment fine fraction $(<63 \mu \mathrm{m})$ in four drainages west of Hanalei, Kauai: Limahuli, Manoa, Wainiha, and Lumahai in summer 2016. The potentially toxic metals $\mathrm{Cr}$ and $\mathrm{Ni}$ exceeded sediment quality guidelines at which adverse biological effects are expected to occur more often than not; however, these metals are mineral-bound in Hawaiian soils and thus are not readily available to organisms. $\mathrm{Cu}$ and $\mathrm{Zn}$ exceeded sediment quality guidelines at which adverse biological effects would sometimes be expected to occur and are also largely geologically sourced in Hawaiian soils. $\mathrm{Cd}$ and $\mathrm{Pb}$ were below levels of ecological concern in fine-grained sediment from the four sampled streams and two back-beach sites. Overall, basaltic geochemical signatures predominated in stream sediment, were relatively similar across basins, and therefore were not distinctive of runoff sources. Alkalic geochemical signatures were identified in fine-grained sediment at two sites: Manoa Stream and a seacliff at Lumahai Beach; however, intertidal beaches and adjacent reef flats contained little fine-grained sediment, which precluded the use of alkalic geochemical signatures in identifying runoff sources and transport along this stretch of shore. The lack of retention of finegrained sediment on beaches of the north shore of Kauai west of Hanalei attests to the efficiency of removal of land-derived sediment and sediment-bound contaminants by local hydrodynamics in summer. Although rainfall is greater in winter than summer on Kauai (Ramage and Schroeder, 1999) and could
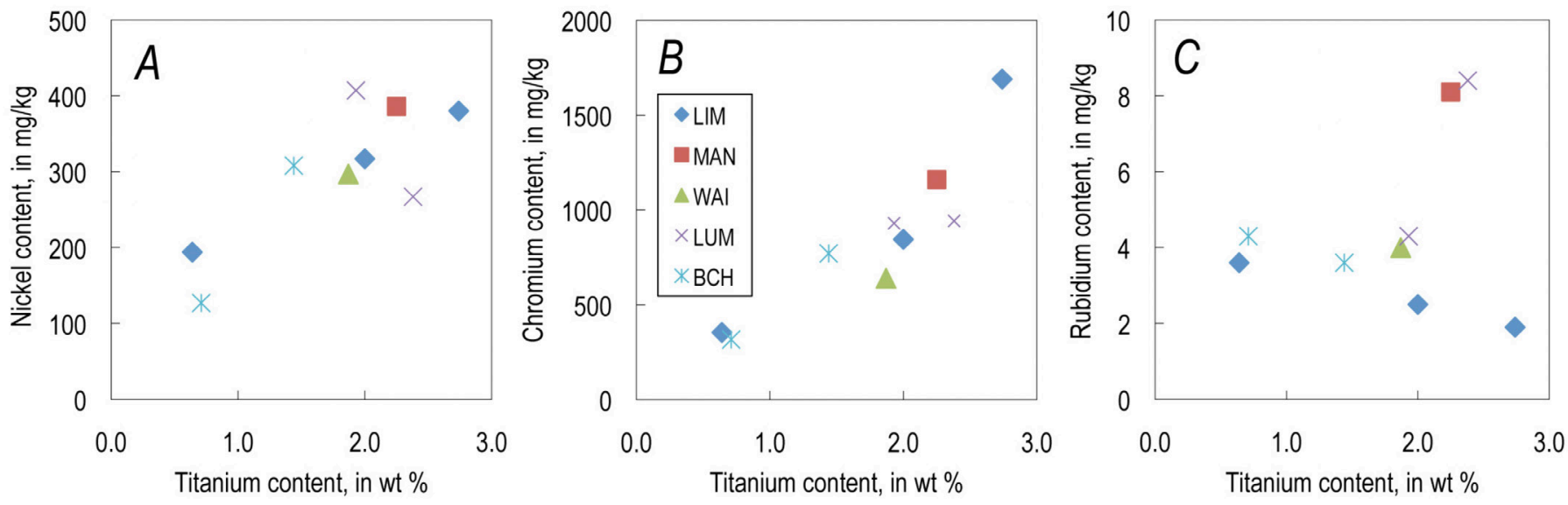

Figure 2. Scatter plots of $(A)$ nickel, $(B)$ chromium, and $(C)$ rubidium contents relative to titanium contents in fine sediment from Limahuli Stream (LIM), Manoa Stream (MAN), Wainiha Stream (WAI), Lumahai Stream (LUM), and the back beaches (BCH) of Limahuli and of Wainiha. wt \%, percentage by weight. 
deliver more runoff to the coastal ocean, terrigenous sediment removal is expected to be more efficient in winter when large wave events impact the north shore (Moberly, 1968) and offset negative effects of terrigenous sediment loading (Draut and others, 2009).

\section{Acknowledgments}

Cathy Gewecke of the Hawaii State Department of Land and Natural Resources, Division of Aquatic Resources, assisted with permitting. Maka ala Ka`aumoana of the Hanalei Watershed Hui and Kawika Winter of the Limahuli Garden and Preserve provided input about the study. Leticia Hallas and Angela Tan assisted with sample preparation and analyses. Nancy Prouty and Daniel Hoover provided comments that improved the manuscript. Funding for this work was provided by the U.S. Geological Survey Coastal and Marine Geology Program.

\section{References}

Aeby, G.S., Williams, G.J., Franklin, E.C., Kenyon, J., Cox, E.F., Coles, S., and Work, T.M., 2011, Patterns of coral disease across the Hawaiian Archipelago-Relating disease to environment: PLoS One, v. 6, no. 5, p. e20370. https://doi. org/10.1371/journal.pone.0020370.

Calhoun, R.S., and Fletcher, C.H., 1996, Late Holocene coastal plain stratigraphy and sea-level history at Hanalei, Kauai, Hawaiian Islands: Quaternary Research, v. 45, no. 01, p. 47-48. https://doi.org/10.1006/qres.1996.0005.

Cousens, B.L., and Clague, D.A., 2015, Shield to rejuvenated stage volcanism on Kauai and Niihau, Hawaiian Islands: Journal of Petrology, v. 56, no. 8, p. 1547-1584. https://doi. org/10.1093/petrology/egv045.

Draut, A.E., Bothner, M.H., Field, M.E., Reynolds, R.L., Cochran, S.A., Logan, J.B., Storlazzi, C.D., and Berg, C.J., 2009, Supply and dispersal of flood sediment from a steep, tropical watershed-Hanalei Bay, Kaua'i, Hawai'i, USA: Geological Society of America Bulletin, v. 121, no. 3/4, p. 574-585. https://doi.org/10.1130/B26367.1.

Folk, R.L., and Ward, W.C., 1957, Brazos River bar [Texas]A study in the significance of grain size parameters: Journal of Sedimentary Research, v. 27, no. 1, p. 3-26. https://doi. org/10.1306/74D70646-2B21-11D7-8648000102C1865D.

Fralick, P.W., and Kronberg, B.I., 1997, Geochemical discrimination of clastic sedimentary rock sources: Sedimentary Geology, v. 113, no. 1-2, p. 111-124. https://doi. org/10.1016/S0037-0738(97)00049-3.
Garcia, M.O., Swinnard, L., Weis, D., Greene, A.R., Tagami, T., Sano, H., and Gandy, C.E., 2010, Petrology, geochemistry, and geochronology of Kaua'i lavas over 4.5 MyrImplications for the origin of rejuvenated volcanism and the evolution of the Hawaiian plume: Journal of Petrology, v. 51, no. 7, p. 1507-1540. https://doi.org/10.1093/petrology/egq027.

Goldhaber, M.B., Morrison, J.M., Holloway, J.M., Wanty, R.B., Helsel, D.R., and Smith, D.B., 2009, A regional soil and sediment geochemical study in northern California: Applied Geochemistry, v. 24, no. 8, p. 1482-1499. https:// doi.org/10.1016/j.apgeochem.2009.04.018.

Hanano, D., Weis, D., Scoates, J.S., Aciego, S., and DePaolo, D.J., 2010, Horizontal and vertical zoning of heterogeneities in the Hawaiian mantle plume from the geochemistry of consecutive postshield volcano pairs - KohalaMahukona and Mauna Kea-Hualalai: Geochemistry Geophysics Geosystems, v. 11, no. 1, Q01004. https://doi. org/10.1029/2009GC002782.

Hawaii Department of Health, 2015, Hawai i's nonpoint source management plan 2015-2020: Hawai i State Department of Health Clean Water Branch Polluted Runoff Control Program, Honolulu, 94 p., https://doi.org/http://hawaii. gov/doh/pollutedrunoffcontrol.

Hawaii Department of Transportation, 2017, Highways Program Status: Hawaii Department of Transportation web page, accessed November 28, at https://histategis.maps. arcgis.com/apps/MapSeries/index.html?appid=39e4d80424 2740a89d3fd0bc76d8d7de.

Long, E.R., MacDonald, D.D., Smith, S.L., and Calder, F.D., 1995, Incidence of adverse biological effects within ranges of chemical concentrations in marine and estuarine sediments: Environmental Management, v. 19, no. 1, p. 81-97. https://doi.org/10.1007/BF02472006.

Maaløe, S., James, D., Smedley, P., Petersen, S., and Garmann, L.B., 1992, The Koloa volcanic suite of Kauai, Hawaii: Journal of Petrology, v. 33, no. 4, p. 761-784. https://doi. org/10.1093/petrology/33.4.761.

MacDonald, D.D., Ingersoll, C.G., and Berger, T.A., 2000, Development and evaluation of consensus-based sediment quality guidelines for freshwater ecosystems: Archives of Environmental Contamination and Toxicology, v. 39, no. 1, p. 20-31. https://doi.org/10.1007/s002440010075.

MacDonald, G.A., Davis, G.A., and Cox, D.C., 1960, Geology and ground-water resources of the Island of Kauai, Hawaii: Hawaii Division of Hydrography, Bulletin 13, 212 p.

Mee, L., 2012, Between the devil and the deep blue sea-The coastal zone in an era of globalisation: Estuarine, Coastal and Shelf Science, v. 96, p. 1-8. https://doi.org/10.1016/j. ecss.2010.02.013 
Moberly, R., Jr., 1968, Loss of Hawaiian littoral sand: Journal of Sedimentary Petrology, v. 38, no. 1, p. 17-34.

Morrison, J.M., Goldhaber, M.B., Lee, L., Holloway, J.M., Wanty, R.B., Wolf, R.E., and Ranville, J.F., 2009, A regionalscale study of chromium and nickel in soils of northern California, USA: Applied Geochemistry, v. 24, no. 8, p. 15001511. https://doi.org/10.1016/j.apgeochem.2009.04.027.

Morton, R.A., Gelfenbaum, G., and Jaffe, B.E., 2007, Physical criteria for distinguishing sandy tsunami and storm deposits using modern examples: Sedimentary Geology, v. 200, no. 3-4, p. 184-207. https://doi.org/10.1016/j.sedgeo.2007.01.003.

Mukhopadhyay, S., Lassiter, J.C., Farley, K.A., and Bogue, S.W., 2003, Geochemistry of Kauai shield-stage lavas - Implications for the chemical evolution of the Hawaiian plume: Geochemistry Geophysics Geosystems, v. 4, no. 1. https://doi. org/10.1029/2002GC000342.

Ramage, C.S., and Schroeder, T.A., 1999, Trade wind rainfall atop Mount Waialeale, Kauai: Monthly Weather Review, v. 127 , no. 9 , p. 2217-2226. https://doi.org/10.1175/15200493(1999)127<2217:TWRAMW>2.0.CO;2.

Sherrod, D.R., Sinton, J.M., Watkins, S.E., and Brunt, K.M., 2007, Geologic Map of the State of Hawai'i: US Geological Survey Open-File Report 2007-1089: Reston, 85 p., https://doi. org/10.3133/ofr20071089.

Sutherland, R.A., 2000, Bed sediment-associated trace metals in an urban stream, Oahu, Hawaii: Environmental Geology, v. 39, no. 6, p. 611-627. https://doi.org/10.1007/s002540050473.

Sutherland, R.A., and Tolosa, C.A., 2000, Multi-element analysis of road-deposited sediment in an urban drainage basin, Honolulu, Hawaii: Environmental Pollution, v. 110, no. 3, p. 483495. https://doi.org/10.1016/S0269-7491(99)00311-5. 


\section{Appendix 1. Sediment Geochemical Compositions from Near-Total Digestions}

[LIM, Limahuli Stream; MAN, Manoa Stream; WAI, Wainiha Stream; LUM, Lumahai Stream; (B), beach sediment; mg/kg, milligrams per kilogram. Site identification numbers correspond to locations given in table 1.]

\begin{tabular}{|c|c|c|c|c|c|c|c|c|c|}
\hline Element & LIM-2 & LIM-5 & LIM-7 & MAN-2 & WAI-5 & LUM-1 & LUM-4 & LIM-9 (B) & WAI-7 (B) \\
\hline \multicolumn{10}{|c|}{ Major elements, in percent } \\
\hline $\mathrm{Al}$ & 7.01 & 7.48 & 2.78 & 2.79 & 6.44 & 6.78 & 5.2 & 6.61 & 9.28 \\
\hline $\mathrm{C}$ & 3.38 & 2.7 & 6.77 & 7.15 & 5.62 & 2.16 & 4.09 & 3.17 & 0.88 \\
\hline $\mathrm{Fe}$ & 9.86 & 11.9 & 6.84 & 3.84 & 11.8 & 9.23 & 7.73 & 10.5 & 14 \\
\hline $\mathrm{K}$ & 0.08 & 0.07 & 0.07 & 0.17 & 0.19 & 0.1 & 0.1 & 0.11 & 0.25 \\
\hline $\mathrm{Mg}$ & 1.49 & 2.58 & 0.89 & 1.96 & 3.74 & 1.52 & 2.54 & 2.21 & 0.83 \\
\hline $\mathrm{Na}$ & 0.21 & 0.34 & 0.15 & 0.96 & 0.47 & 0.31 & 0.37 & 0.36 & 0.25 \\
\hline $\mathrm{S}$ & 0.15 & 0.1 & 0.36 & 0.4 & 0.16 & 0.15 & 0.18 & 0.16 & 0.14 \\
\hline $\mathrm{Ti}$ & 1.83 & 2.44 & 0.62 & 0.65 & 2.03 & 1.71 & 1.32 & 1.77 & 2.24 \\
\hline \multicolumn{10}{|c|}{ Minor and trace elements, in $\mathrm{mg} / \mathrm{kg}$} \\
\hline $\mathrm{Ag}$ & 0.23 & 0.24 & 0.1 & 0.16 & 0.51 & 0.3 & 0.25 & 0.32 & 0.48 \\
\hline As & 4.7 & 2.2 & 14.1 & 13.4 & 9.6 & 3.4 & 11.4 & 17.5 & 4.5 \\
\hline $\mathrm{Ba}$ & 78 & 86 & 53 & 35 & 237 & 115 & 56 & 87 & 149 \\
\hline $\mathrm{Be}$ & 0.95 & 0.93 & 0.32 & 0.32 & 0.95 & 1.03 & 0.69 & 0.89 & 1.48 \\
\hline $\mathrm{Bi}$ & 0.06 & 0.04 & 0.05 & 0.13 & 0.84 & 0.05 & 0.31 & 0.07 & 0.08 \\
\hline $\mathrm{Cd}$ & 0.21 & 0.19 & 0.1 & 0.12 & 0.28 & 0.15 & 0.09 & 0.23 & 0.12 \\
\hline $\mathrm{Ce}$ & 26.7 & 21.2 & 14.2 & 11.6 & 40.1 & 36.3 & 29.7 & 32.1 & 51.4 \\
\hline $\mathrm{Co}$ & 69.1 & 75.4 & 36.4 & 26.5 & 72.4 & 59.4 & 58.1 & 74.9 & 78.1 \\
\hline $\mathrm{Cr}$ & 593 & 1030 & 249 & 218 & 846 & 497 & 486 & 672 & 728 \\
\hline $\mathrm{Cs}$ & 0.23 & 0.14 & 0.3 & 0.19 & 0.6 & 0.34 & 0.29 & 0.42 & 0.58 \\
\hline $\mathrm{Cu}$ & 127 & 160 & 48.6 & 69.3 & 207 & 110 & 94.6 & 96.8 & 144 \\
\hline $\mathrm{Ga}$ & 25.1 & 28 & 10.1 & 9.66 & 26.6 & 24.2 & 19.9 & 24 & 36.8 \\
\hline In & 0.079 & 0.091 & 0.024 & 0.027 & 0.079 & 0.07 & 0.055 & 0.074 & 0.105 \\
\hline $\mathrm{La}$ & 14 & 10 & 6.2 & 5.3 & 20.8 & 18.3 & 14.5 & 15.6 & 30 \\
\hline $\mathrm{Li}$ & 10 & 9.5 & 7.5 & 13.5 & 11.4 & 7.9 & 17 & 16.3 & 19 \\
\hline $\mathrm{Mn}$ & 1640 & 1210 & 945 & 652 & 1180 & 1200 & 1260 & 1670 & 1580 \\
\hline Mo & 0.92 & 0.87 & 0.73 & 0.8 & 2.51 & 1.03 & 0.99 & 1.27 & 2.4 \\
\hline $\mathrm{Nb}$ & 14.8 & 17.8 & 5.9 & 6.3 & 37.6 & 22.5 & 15.4 & 20.7 & 38 \\
\hline $\mathrm{Ni}$ & 290 & 340 & 184 & 117 & 351 & 277 & 293 & 390 & 271 \\
\hline $\mathrm{P}$ & 1490 & 1230 & 2160 & 2000 & 1640 & 1870 & 1470 & 2230 & 1540 \\
\hline $\mathrm{Pb}$ & 2.8 & 2.1 & 7.8 & 8.3 & 26.1 & 3.4 & 3.3 & 32.8 & 7.3 \\
\hline $\mathrm{Rb}$ & 2.4 & 1.8 & 3.3 & 3.9 & 7.6 & 3.6 & 3.3 & 4.2 & 8.9 \\
\hline $\mathrm{Sb}$ & 0.07 & $<0.05$ & 0.21 & 0.37 & 7.22 & 0.09 & 0.19 & 0.32 & 0.2 \\
\hline $\mathrm{Sc}$ & 32.7 & 36.9 & 12.1 & 12.8 & 31.4 & 29.3 & 24.4 & 30.2 & 40.2 \\
\hline $\mathrm{Sn}$ & 2.5 & 2.3 & 3.1 & 2.2 & 17 & 2.6 & 2.9 & 5.6 & 3.1 \\
\hline $\mathrm{Sr}$ & 245 & 131 & 668 & 491 & 372 & 156 & 330 & 287 & 100 \\
\hline $\mathrm{Ta}$ & 1.11 & 1.35 & 0.42 & 0.47 & 2.37 & 1.58 & 1.1 & 1.48 & 2.67 \\
\hline $\mathrm{Tb}$ & 1.03 & 0.83 & 0.44 & 0.4 & 0.99 & 1.04 & 0.87 & 0.91 & 1.64 \\
\hline $\mathrm{Te}$ & $<0.01$ & 0.03 & 0.05 & 0.05 & 0.07 & $<0.01$ & 0.01 & 0.04 & 0.07 \\
\hline
\end{tabular}




\section{Appendix 1. Sediment Geochemical Compositions from Near-Total Digestions- Continued.}

\begin{tabular}{lccccccccc}
\hline Element & LIM-2 & LIM-5 & LIM-7 & MAN-2 & WAI-5 & LUM-1 & LUM-4 & LIM-9 (B) & WAI-7 (B) \\
\hline Th & 1 & 0.9 & 0.8 & 0.6 & 3 & 1.8 & 1.4 & 1.7 & 3.4 \\
Tl & 0.03 & 0.02 & 0.03 & 0.03 & 0.04 & 0.03 & 0.02 & 0.04 & 0.04 \\
U & 0.588 & 0.383 & 1.65 & 0.886 & 1.34 & 0.764 & 0.799 & 1.07 & 1.27 \\
V & 316 & 435 & 140 & 114 & 360 & 286 & 227 & 317 & 422 \\
W & 0.6 & 0.5 & 0.5 & 0.3 & 0.7 & 0.5 & 0.3 & 0.4 & 0.5 \\
Zn & 140 & 177 & 115 & 74.4 & 282 & 129 & 105 & 172 & 168 \\
\hline
\end{tabular}

\section{Appendix 2. Sediment Geochemical Compositions from Total Digestions}

[LIM, Limahuli Stream; MAN, Manoa Stream; WAI, Wainiha Stream; LUM, Lumahai Stream; (B), beach sediment; mg/kg, milligrams per kilogram. Site identification numbers correspond to locations given in table 1.]

\begin{tabular}{|c|c|c|c|c|c|c|c|c|c|}
\hline Element & LIM-2 & ㄴIM-5 & LIM-7 & MAN-2 & WAI-5 & LUM-1 & LUM-4 & LIM-9 (B) & WAI-7 (B) \\
\hline \multicolumn{10}{|c|}{ Major elements, in percent } \\
\hline $\mathrm{Al}$ & 7.45 & 8.1 & 2.82 & 2.94 & 6.91 & 7.17 & 5.67 & 6.84 & 9.75 \\
\hline $\mathrm{Ca}$ & 3.6 & 2.89 & 7.36 & 7.61 & 5.91 & 2.26 & 4.29 & 3.28 & 0.91 \\
\hline $\mathrm{Fe}$ & 10.4 & 12.6 & 7 & 4.03 & 12.3 & 9.75 & 8.49 & 10.9 & 13.7 \\
\hline $\mathrm{K}$ & 0.07 & 0.07 & 0.08 & 0.17 & 0.2 & 0.09 & 0.09 & 0.11 & 0.24 \\
\hline $\mathrm{Mg}$ & 1.61 & 2.75 & 0.94 & 2.11 & 3.97 & 1.59 & 2.78 & 2.25 & 0.88 \\
\hline $\mathrm{P}$ & 0.14 & 0.12 & 0.21 & 0.19 & 0.16 & 0.18 & 0.13 & 0.2 & 0.14 \\
\hline $\mathrm{S}$ & 0.1 & $<0.1$ & 0.4 & 0.4 & 0.2 & 0.1 & 0.2 & 0.2 & 0.1 \\
\hline $\mathrm{Si}$ & 12.3 & 15.1 & 5.96 & 6.07 & 14.2 & 15.4 & 15.1 & 13.4 & 11.7 \\
\hline $\mathrm{Ti}$ & 2 & 2.74 & 0.64 & 0.71 & 2.25 & 1.87 & 1.44 & 1.93 & 2.38 \\
\hline \multicolumn{10}{|c|}{ Minor and trace elements, in $\mathrm{mg} / \mathrm{kg}$} \\
\hline $\mathrm{Ag}$ & $<1$ & $<1$ & $<1$ & $<1$ & $<1$ & $<1$ & $<1$ & $<1$ & $<1$ \\
\hline As & $<5$ & $<5$ & 12 & 15 & 8 & $<5$ & 8 & 18 & $<5$ \\
\hline $\mathrm{Ba}$ & 85.1 & 90.8 & 56 & 33.5 & 245 & 120 & 57.3 & 90.2 & 160 \\
\hline $\mathrm{Be}$ & $<5$ & $<5$ & $<5$ & $<5$ & $<5$ & $<5$ & $<5$ & $<5$ & $<5$ \\
\hline $\mathrm{Bi}$ & $<0.1$ & $<0.1$ & $<0.1$ & 0.1 & 0.8 & $<0.1$ & 0.3 & $<0.1$ & $<0.1$ \\
\hline $\mathrm{Cd}$ & 0.3 & 0.3 & $<0.2$ & $<0.2$ & 0.3 & $<0.2$ & $<0.2$ & 0.4 & $<0.2$ \\
\hline $\mathrm{Ce}$ & 33 & 25.6 & 17.1 & 13.8 & 47.8 & 42.4 & 35.7 & 38.5 & 60.9 \\
\hline Co & 66.4 & 76.6 & 36.6 & 26.4 & 72.5 & 56.8 & 57 & 70.8 & 74 \\
\hline $\mathrm{Cr}$ & 845 & 1690 & 354 & 317 & 1160 & 640 & 771 & 930 & 942 \\
\hline $\mathrm{Cs}$ & 0.2 & 0.2 & 0.3 & 0.2 & 0.7 & 0.4 & 0.3 & 0.4 & 0.6 \\
\hline $\mathrm{Cu}$ & 152 & 190 & 55 & 73 & 240 & 127 & 106 & 112 & 161 \\
\hline Dy & 6.08 & 5.09 & 2.64 & 2.35 & 5.46 & 5.5 & 4.71 & 5.13 & 8.89 \\
\hline $\mathrm{Er}$ & 3.04 & 2.57 & 1.33 & 1.19 & 2.38 & 2.4 & 2.55 & 2.55 & 3.97 \\
\hline $\mathrm{Eu}$ & 2.28 & 1.76 & 0.95 & 0.84 & 2.15 & 2.35 & 1.94 & 2.12 & 3.91 \\
\hline $\mathrm{Ga}$ & 22.6 & 25.5 & 8.85 & 9.97 & 24.8 & 21.6 & 18 & 21.6 & 33 \\
\hline $\mathrm{Gd}$ & 7.61 & 6.12 & 3.15 & 3 & 6.98 & 7.21 & 6.69 & 6.72 & 12.1 \\
\hline $\mathrm{Ge}$ & 1 & 2 & $<1$ & $<1$ & 2 & 1 & 1 & 1 & 2 \\
\hline
\end{tabular}




\section{Appendix 2. Sediment Geochemical Compositions from Total Digestions- Continued.}

\begin{tabular}{|c|c|c|c|c|c|c|c|c|c|}
\hline Element & LIM-2 & LIM-5 & LIM-7 & MAN-2 & WAI-5 & LUM-1 & LUM-4 & LIM-9 (B) & WAI-7 (B) \\
\hline $\mathrm{Hf}$ & 4 & 5 & 2 & 2 & 6 & 4 & 4 & 4 & 6 \\
\hline Ho & 1.29 & 0.99 & 0.57 & 0.47 & 1 & 1.14 & 1.01 & 1.11 & 1.78 \\
\hline In & $<0.2$ & $<0.2$ & $<0.2$ & $<0.2$ & $<0.2$ & $<0.2$ & $<0.2$ & $<0.2$ & $<0.2$ \\
\hline $\mathrm{La}$ & 15.4 & 10.9 & 6.7 & 5.5 & 22.6 & 19 & 16.1 & 16.8 & 32.4 \\
\hline $\mathrm{Li}$ & $<10$ & $<10$ & $<10$ & 12 & $<10$ & $<10$ & 15 & 16 & 19 \\
\hline $\mathrm{Lu}$ & 0.34 & 0.28 & 0.15 & 0.15 & 0.29 & 0.26 & 0.3 & 0.26 & 0.44 \\
\hline $\mathrm{Mn}$ & 1780 & 1200 & 1010 & 692 & 1200 & 1220 & 1340 & 1690 & 1610 \\
\hline Mo & $<2$ & $<2$ & $<2$ & $<2$ & 3 & $<2$ & $<2$ & $<2$ & 2 \\
\hline $\mathrm{Nb}$ & 14.7 & 19.5 & 6 & 6.8 & 40.9 & 23.6 & 16.4 & 21.5 & 37.6 \\
\hline $\mathrm{Nd}$ & 25.5 & 18.9 & 10.8 & 9.5 & 28.1 & 27 & 23.5 & 23.8 & 47.6 \\
\hline $\mathrm{Ni}$ & 317 & 380 & 194 & 127 & 386 & 297 & 308 & 407 & 267 \\
\hline $\mathrm{Pb}$ & $<5$ & $<5$ & 8 & 8 & 30 & $<5$ & $<5$ & 35 & 7 \\
\hline $\operatorname{Pr}$ & 5.13 & 3.83 & 2.16 & 1.82 & 6.13 & 5.58 & 4.72 & 5.4 & 10.2 \\
\hline $\mathrm{Rb}$ & 2.5 & 1.9 & 3.6 & 4.3 & 8.1 & 4 & 3.6 & 4.3 & 8.4 \\
\hline $\mathrm{Sb}$ & $<0.1$ & $<0.1$ & 0.2 & 0.3 & 8 & $<0.1$ & 0.2 & 0.4 & 0.2 \\
\hline $\mathrm{Sc}$ & 36 & 41 & 13 & 14 & 34 & 31 & 26 & 32 & 43 \\
\hline $\mathrm{Se}$ & $<5$ & $<5$ & $<5$ & $<5$ & $<5$ & $<5$ & $<5$ & $<5$ & $<5$ \\
\hline $\mathrm{Sm}$ & 6 & 4.6 & 2.5 & 2.4 & 5.8 & 6.2 & 4.8 & 5.1 & 10.5 \\
\hline $\mathrm{Sn}$ & 2 & 3 & 4 & 3 & 18 & 2 & 2 & 7 & 3 \\
\hline $\mathrm{Sr}$ & 281 & 138 & 748 & 592 & 424 & 178 & 370 & 327 & 103 \\
\hline $\mathrm{Ta}$ & 0.9 & 1.1 & $<0.5$ & $<0.5$ & 2.2 & 1.3 & 0.9 & 1.3 & 2.2 \\
\hline $\mathrm{Tb}$ & 1.17 & 0.9 & 0.48 & 0.39 & 0.97 & 1.01 & 0.93 & 0.97 & 1.74 \\
\hline $\mathrm{Te}$ & $<0.5$ & $<0.5$ & $<0.5$ & $<0.5$ & $<0.5$ & $<0.5$ & $<0.5$ & $<0.5$ & $<0.5$ \\
\hline $\mathrm{Th}$ & 0.9 & 0.8 & 0.8 & 0.6 & 3.2 & 1.8 & 1.4 & 1.8 & 3.3 \\
\hline $\mathrm{Tl}$ & $<0.5$ & $<0.5$ & $<0.5$ & $<0.5$ & $<0.5$ & $<0.5$ & $<0.5$ & $<0.5$ & $<0.5$ \\
\hline $\mathrm{Tm}$ & 0.41 & 0.37 & 0.22 & 0.14 & 0.32 & 0.34 & 0.34 & 0.39 & 0.63 \\
\hline $\mathrm{U}$ & 0.63 & 0.41 & 1.68 & 0.9 & 1.32 & 0.81 & 0.84 & 1.06 & 1.28 \\
\hline $\mathrm{V}$ & 321 & 487 & 149 & 124 & 402 & 293 & 259 & 321 & 459 \\
\hline W & $<1$ & $<1$ & $<1$ & $<1$ & $<1$ & $<1$ & $<1$ & $<1$ & $<1$ \\
\hline $\mathrm{Y}$ & 31.3 & 23.9 & 15.6 & 12.8 & 25.8 & 29.3 & 24.1 & 26.3 & 39.7 \\
\hline $\mathrm{Yb}$ & 2.4 & 1.9 & 1 & 1 & 2 & 2.1 & 1.9 & 2.1 & 3.3 \\
\hline $\mathrm{Zn}$ & 148 & 192 & 124 & 79 & 293 & 128 & 111 & 177 & 166 \\
\hline $\mathrm{Zr}$ & 158 & 188 & 65.1 & 61.7 & 228 & 173 & 140 & 172 & 230 \\
\hline
\end{tabular}

Menlo Park and Tacoma Publishing Service Centers, California and Washington

Manuscript approved February 6, 2019

Edited by Jeff Suwak

Layout by Vivian Nguyen 


\section{$\frac{\mathbb{3}}{3}$}

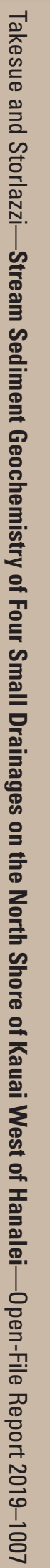

